Carter has given a good description of his species theobaldi and mentioned all its diagnostic characters. The species is readily recognizable in the Tondaung limestone. The name proposed by him is therefore valid and has priority over elephantina, which is, however, too well established to be suppressed. The species occurs in the Upper Nari (Chattian) of North West India (Vredenburg ${ }^{3}$ ), Aquitanian of Persia (Böckh, Lees and Richardson 8 , Upper Oligocene of Palestine, species has so far not been reported from the zone of reticulate Nummulites.

Eu. formosa shows considerable variation both in its external and internal features. The nephrolepidine-type of embryonic apparatus is occasionally met with and there seems to be little doubt that ephippoides J. and Ch. is identical with formosa. Eu. blanfordi Nuttallio described from the Gaj of North West India appears to be the microspheric form of formosa. The American species described by Thiadens ${ }^{11}$ as formosa has polygonal lateral chambers and is not be confused with the oriental species, in which the lateral chambers are always circular or sub-circular.

Neph. sondaica is a small form of the marginata-type and shows resemblance to Lep. (L.) formosensis $\mathrm{H}_{\mathrm{H}}$. resembies Lep. (L.) yurnagunensis Cushman ${ }^{18}$. Study of the developmental species Lep. (L.) yurnagunensis Cushman's. Study of the developmental
stages of the microspheric and megalospheric forms of nephrolepidines stages of the microspheric and megalospheric forms of nephrolepidines intermediate between Lepidocyclina (s. str.) formosensis of the older intermediate between Lepidocyclina (s. str.) formosensis of the older beds and nephrolepidines (sumatrensis and tournoueri) found in the
younger Upper Gaj (Burdigalian) beds. The distinction which Doluvillé younger Upper Gaj (Burdigalian) beds. The distinction which Douville
recognized between the marginata-type and the sumatrensis-type seems recognized between the marginata-type and the sumatrensis-type seems
to be justified. It is interesting to note that the genus Tryblilepidina characteristic of the higher Miocene beds in the Indo-Pacific region is a stellate form (Crespin ${ }^{14}$ ). A stellate test a mong orbitoids and is a stellate form (Crespin ${ }^{16}$ ). A stellate test among orbitoids and
discocyclines appears to represent a late stage in their evolutionary discocycines appears to represent a late stage in their evolutionary
development. We thus recognize three groups of nephrolepidines both development. We thus recognize three groups of nephrolepidines both
on structural and stratigraphical grounds: (1) sondaica-type, (2) on structural and stratigraphical grounds: (1) sondaic

The following points are made out regarding the age of the fauna.
The The presence of Nephrolepidina and Eu. elephantina deflnitely rules out a Stampian age. The fauna is older than the Upper Gaj (Burdigalian) fauna from Surat ${ }^{15}$ in which I have identifled: Neph. sumatrensis, Neph. tournoueri, Neph. proetournoueri, Miogypsina sp., and Trillina
howchini. The choice therefore lieb between Chattian and Aquitanian. howchini. The choice therefore lieb between Chattian and Aquitanian.
A Chattian age seems to be most probable because: (1) of the presence of Neph. sondaica, which I recognize to be an early primitive form, (2) of the absence of Miogypsinidoe ${ }^{16}$, and (3) of the fleld evidence, which places the Lepidocyclina horizon in the Oligocene and not in the Lower Miocene. (I have noticed Miogypsina in a Lepidocyclina-limestone of Lower Miocene (Aquitanian?) age from the Andaman Islands; it is also clearly seen in a photo given by Mr. Gee in

geology of the Andaman and Nicobar Islandis's.)
The fauna listed by me does not fit into the 'd' stage of the East Indies. The ' $d$ ' stage is characterized by reticulate Nummulites, Eulepidina and Lepidocyclina s.str. It is curious that while reticulate Nummulites are found in Java, Borneo and Papua, they have not so far been found in Burma. The Tondaung fauna has to be correlated with the lower 'e' stage. The ' $e$ ' stage, according to Van der Vlerk'17 and Miss Crespin 18 , corresponds to the Aquitanian of Europe, and the Aquitanian.

Geology Department,
Intermediate College,

S. R. NARAYANA RAO.

$$
\begin{aligned}
& \text { Bangalore. } \\
& \text { Sept. } 12 .
\end{aligned}
$$

'Rao, S. R. N., Rec. Geol. Surv. Ind., 77 (Prof. paper 12), 1 (1942). ${ }^{2}$ Carter, H. J., Ann. Mag. Nat. Hist,, 2, 342 (1888).

Vredenburg, E., Rec. Geol. Sur. Ind., 51, $326(1920)$.

- Cotter, G. de P., Mem. Geol. Sur. Ind., 72 (1), (1938).

- Lepper, G. W., Proc. World Pet. Cong., 1 (1933).

$?$ Evans, P., Geol. Mag., 78, 332 (1941)

Böckh, H.'de, Lees, G. M., and Richardson, F. D. S., "The Structure of Asia;,, 157 (1929)

'Henson, F. R. S., C.R. Acad. Sci., Paris, 202, 2 (1936).

1 Thiadens, A. A., J. Pal., 11, 105 (1937).

12 Hanzawa, S., Proc. Imp. Acad., Tokyo, 15, 182 (1939).

13 Vaughan, T. W., Quart. J. Geol.' Soc., 82, 391 (1926).

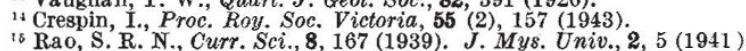

16 Rec. Geol. Surv. Ind., 59, pl. 15, flg. 3 (1926)

1; Van der Vlerk, I. M., Leid. Geol. Meded., 5, 207 (1931).

10 Glaessner, M. F., Proc. Roy. Soc. Victoria, 55 (n.s.), Table (1943).

\section{Nepalese Blood Groups}

A RRCent tour of duty with the Army in India provided me with an opportunity of testing the blood groups of a number of Gurkha troops, natives of Nepal.

Tests were made on 2,869 men and the results were :

$\begin{array}{ccccccc}\text { Group } & A B & \ldots & . & . & 9 \cdot 2 & \text { per cent } \\ , " & A & . & . & . & 33.8 & , \\ , & B & . & . & . & 25 \cdot 2 & , \\ , & 0 & . & . & . & 31.8 & , "\end{array}$

The calculated gene frequencies are $p=0.245, q=0.190, r=0.564$. This distribution is of Mongolian type, a resnlt to be expected from the strongly Mongolian appearance of the Gurkhas. It differs con siderably from the distribution in the contiguous Indian population,
in whom the above frequencies of groups $A$ and $B$ are roughly interchanged.

University, Melbourne, N.3.

\section{Science and Reconstruction}

THE lecture by Sir John Anderson publishęd in Nature of December 22 , p. 733, does but seant justice to British chemical industry prior to the First World War. The statement that "the only industrial openings one heard of were occasional vacancies in breweries" is not in accordance with the facts, and takes no cognizance of the existence of a great inorganic chemical industry represented by such flrms as
Brünner, Mond and $\mathrm{Co}$. and the United Alkali Co. and numerous Brünner, Mond and Co. and the United Alkali Co., and numerous
manufacturers of acids and phosphatic fertilizers and a considerable manufacturers of acids and phosphatic fertilizers and a considerable organic industry represented by the works of Read Holliday, Leven-
stein, British Alizarine, Clauss and Co., and many others, not to speak of the explosives manufacturers of Nobels in Scotland and $\mathrm{K}$ ynoctis in Ireland.

All these firms employed chemists, and a considerable proportion of those turned out by the universities each year obtained employment in industry. To quote one small example well known to me, the Royal College of Science for Ireland turned out each year ten to twelve qualified chemists, and on the average sixty per cent of these obtained employment in industry. The great and spectacular growth of the British chemical industry which took place subsequent to 1914 was no spontaneous generation from nothing, and the magnitude of the work that was being done before that date.

\section{Sandbeds, Honley, \\ Huddersfiel}

Sir JoHN ANDERsox states in Nature of December 22, p. 733, that "a good grounding in natural science can be a passport to the higher Civil Service, equally with the more usual training in the humanities, or in the history schools", and that "public administration does provide scope, apart from the professional or specialist grades, for mea with a scientiflic training". Sir John is, of course, quite correct in the sense that the entrance examination for the Administrative Class of Civil Servants can be taken in almost any subject. But in spite of the theoretical possibility, there are very few successful entrants to the Administrative Class with a grounding in natural science. Some flgures on this point may be of interest.

For the years 1925-38, the reports of the Civil Service Commission give the successful entrants with details of their academic training, and I have also been allowed to consult the records for 1939 , a year little affected by the War for present purposes. Taking the Administralittle affected by the War for present purposes. Taking the Administrative Examination proper, that is to say, excluding entrants to the and Diplomatic Services, I find the following for the flfteen years and Diplomatic servis

\begin{tabular}{cc} 
Successful candidate reading & Number \\
Natural science & 14 \\
Geography & 8 \\
Maathematics & 48 \\
Humanities (Hiscory, Languages, \\
Classics, Philosophy, Economics, etc.) \\
Total & $\underline{421}$ \\
\hline
\end{tabular}

Entrance to the administrative grade otherwise than by examinations is also possible; but the proportion among such entrants of Civil servants who have had a scientiflc training is probably smaller still.

I am not concerned to argue whether a training in natural science is better or worse than a training in any other subject for the purposes of administration. I merely point out that, whatever the possibilities, there are in fact only a very small minority of Civil servants in the administrative grade who have had a training in natural science.

507 Hood House,

Dolphin Square, S.W.1.

\section{A Recurrent Nova}

ON February 10 the variable star $T$ Coronæ Borealis, normally of magnitude 9 , was seen to have blazed up to magnitude 3 . This sta had a typical nova outburst in 1866 , when it was the first nova to be examined spectroscopically. Unlike other novæ, its spectrum after fading was of late type with strong absorption bands of titanium oxide. During the last twenty years, its spectrum has varied considerably mainly through the appearance in varying strength of emission lines due to hydrogen, neutral and ionized helium, oxygen and nitrogen. In addition, forbidden lines of oxygen and neon commonly observed in nebulø have been observed.

It is now generally accepted that these lines come from a faint blue companion to the giant red star, which gives the late type spectrum generally observed. This blue star varies in magnitude and is presumably the star responsible for the nova phenomena of 1866 and 1946 . It appears to be surrounded by a stationary gaseous shell, which emits the bright lines referred to above. After eighty years of unrest, this star has once again blown away its outer layers.

Two spectrograms were secured at Cambridge on the morning of Two spectrograms were secured at Cambridge on the morning of been possible since the outburst. The spectra show the usual broad emission hydrogen lines with absorption lines aisplaced to the violet. Thesion hydrogen lines with absorption lines aisplaced to the violet. These lines are also broad, and measures of their edges show that the velocity of outflow of the hydrogen from the star ranges from 500 to
$1,475 \mathrm{~km}$. $/ \mathrm{sec}$. In addition, broad emission lines of helium, oxygen, $1,475 \mathrm{~km}$./ $\mathrm{sec}$. In addition, broad emission lines of helium, oxygen, nitrogen, silicon and possibly sulphur are present. They are very hazy and difficult to measure, but their average widths give a rate of expansion for the shell containing them of less than $350 \mathrm{~km}$. $/ \mathrm{sec}$. the star has been observed for some years before the outburst.

Solar Physics Observatory,

H. BUTLER. 